\title{
Occurrence of Goitre during Lithium Treatment
}

\author{
M. SCHOU,* M.D.; A. AMDISEN,* M.D.; S. ESKJER JENSEN, † M.D. ; T. OLSEN, $\ddagger$ M.D.
}

Brit. med.F., 1968, 3, 710-713

\begin{abstract}
Cummary : Of 330 patients given lithium for recurrent manic-depressive disorder 12 developed goitre after treatment periods of five months to two years. All the patients remained clinically euthyroid. Pressure symptoms necessitated subtotal thyroidectomy in two patients. In 9 out of 10 patients with goitre, and in two out of seven without goitre study with radioactive iodine showed abnormal findings in iodine metabolism. Discontinuance of lithium led to disappearance of goitres, while thyroid metabolism returned to normal. Thyroxine or desiccated thyroid produced shrinkage of the gland in spite of continued lithium medication.
\end{abstract}

\section{Introduction}

Lithium is being used increasingly in the treatment of mania and in the prophylaxis against recurrent manic-depressive disorder (Baastrup and Schou, 1967 ; Schou, 1968). During lithium treatment the development of goitre has occasionally been observed. The present paper is a report on cases from Aarhus University Psychiatric Institute; further cases have been noted in Sweden (Allgén et al., 1967), in Germany (Gonzales and Lauter, 1968), and in other Danish hospitals (Baastrup, 1967 ; Halberg et al., 1968 ; Wiggers, 1968). Careful study of the goitres is important, since lithium has proved invaluable for many patients with manic-depressive disorder. In each of our cases the development of goitre led to careful consideration of whether lithium should be discontinued, but in all the patients manic and depressive relapses had been so frequent and the effect of lithium so convincing that its continuation was indicated.

\section{Clinical Observations}

Goitre developed during lithium treatment in five women and seven men aged 18 to 51 years. They all suffered from recurrent manic-depressive disorder, and lithium carbonate was given as maintenance therapy in doses of $900-2,100 \mathrm{mg}$. per day, corresponding to $24-56 \mathrm{mEq}$ of lithium. Neither the dosages nor the serum lithium concentrations differed between patients who developed goitre and patients who did not, and goitre development was not correlated with the clinical effect of the treatment. Four patients had had no other medication than lithium when goitre developed; the remaining patients had had neuroleptic drugs (perphenazine, thioridazine, haloperidol) or antidepressants (imipramine, desipramine) or both in ordinary therapeutic doses. Thyroid disease was frequent in the family of only one of our patients; the others knew of at most a single instance of goitre or Graves's disease in the family. None of the patients came from or lived in known goitre regions. Two patients ate fish only rarely; the others had no particular dietary habits.

In three patients goitre may have been present before lithium was given, but it increased in size during the treatment. In

\footnotetext{
- Psychopharmacology Research Unit, Aarhus University Psychiatric Institute, Risskov, Denmark

t Second University Clinic of Internal Medicine, Kommunehospitalet, Aarhus, Denmark.

¥ Psychiatric Clinic, Aarhus University Psychiatric Institute, Risskov, Denmark.
}

the remaining nine goitre developed after lithium had been administered for periods of from five months to more than two years. In most of the patients the goitres remained slight or of moderate size and did not produce subjective symptoms ; they were soft and diffuse, in some cases slightly asymmetrical. However, in four patients the goitres became enlarged and caused difficulty in swallowing; more pronounced pressure symptoms in two of these patients necessitated subtotal thyroidectomy: histological examination of the thyroid tissue in one case showed simple colloid goitre, and in the other, who had been treated with diiodotyrosine by her own doctor, nodular goitre with degenerative changes but without signs of malignancy. In these cases lithium concentrations were not determined, but we have had the opportunity of examining tissue from a patient in another hospital. At the time of operation serum lithium was $0.6 \mathrm{mEq} / \mathrm{l}$. and lithium concentration in the thyroid tissue $2.5 \mathrm{mEq} / \mathrm{kg}$. wet weight.

All the patients remained clinically euthyroid.

One of the three patients with slight pretreatment goitre (Case 11) started lithium treatment in March 1967 and became pregnant in May of the same year. During pregnancy her goitre became very large. In January 1968 she gave birth, one month prematurely, to a girl. From this time the goitre decreased somewhat in size. The baby at birth had general oedema and a very large goitre; protein-bound iodine was low. No treatment was given, the oedema abated within a few days, and protein-bound iodine became normal within two weeks. In May the goitre had disappeared; the child developed normally and was clinically euthyroid.

Two patients were negligent regarding their lithium intake. In a third patient lithium was discontinued for experimental reasons ; treatment had to be reinstituted after three months because he became manic. Within two to three months after discontinuance of lithium the goitres decreased in size or disappeared completely. In three patients lithium treatment was supplemented with desiccated thyroid gland or tyroxine; this led in two cases to diminution of the goitre, while in the third patient the goitre remained of constant and moderate size.

\section{Laboratory Investigations}

The usual tests of thyroid function were carried out repeatedly in all the goitre patients. More detailed studies of iodine metabolism were made in 7 of the 12 patients from this clinic and in three patients who were referred to us from other hospitals because they had developed goitre during lithium treatment. Iodine metabolism was also studied in seven patients who had been on lithium maintenance treatment for periods of three months to 13 years without developing goitre.

Protein-bound jodine (P.B.I.) in serum and inorganic iodine in urine were determined by conventional Technicon AutoAnalyzer methods. Estimation of triiodothyronine binding in plasma was carried out as described by Hansen (1966) with the use of Sephadex (Sephadex- $T_{3}$ test) and total serum cholesterol as described by Pearson et al. (1953). The basal metabolic rate was recorded with standard apparatus, and thyroid autoantibody titres were determined as described by Hjort (1963). Iodine metabolism was studied with the use of ${ }^{132}$ I as described by Alexander et al. (1962). For determination of perchlorate discharge the patients were given $500 \mathrm{mg}$. of 
potassium perchlorate two and a half hours after oral intake of ${ }^{132} \mathrm{I}$; counting rates were recorded over neck and thigh during the next 40 minutes.

Alexander et al. (1962) defined the limits of the normal range as "the best separation determined by inspection between the figures obtained from normal individuals and those found in patients with diseases associated with abnormally low or abnormally high values." The ranges shown in the Table are based on experiences with Danish patients and control subjects (Jensen, 1968).

Five patients (Cases 3, 4, 8, 11, and 12) were subjected to only the conventional thyroid tests, which did not disclose anomalies. In one patient (Case 11) the Sephadex- $T_{3}$ test was $2.2 \%$ in January 1968 ; this is not abnormal late in pregnancy.

The Table shows the results obtained with the 10 patients subjected to investigation with ${ }^{132}$ I. In only one patient (Case 10) were the readings entirely normal. In six patients tracer uptake at two and a half hours was raised. Thyroid iodine clearance was increased in nine patients-considerably in six, and moderately in three. In eight patients inorganic plasma iodine was below the normal range at one or more investigations; in one patient (Case 1) it was near the upper normal limit. Absolute iodine uptake showed increase at one or more investigations in six patients. Renal iodide clearance was increased in four patients. There was no instance of perchlorate discharge.

P.B.I. was low in two patients (Cases 5 and 13), but the average P.B.I. value of the goitre patients did not differ significantly from that of normal persons or from the average P.B.I. value in lithium-treated patients without goitre. Suppression test with triiodothyronine was carried out in one patient (Case 1). Tracer uptake at two and a half hours fell from 36 to $4 \%$ and thyroid clearance from 107 to $27 \mathrm{ml} . / \mathrm{min}$.

Lithium was discontinued for experimental reasons in one patient (Case 1). After three months without lithium, tracer uptake at two and a half hours had decreased from 36 to $17 \%$, thyroid clearance had become normal $(28 \mathrm{ml} . / \mathrm{min}$.$) , and$ absolute iodine uptake had fallen from 16.0 to $7.2 \mu \mathrm{g}$./hour. Inorganic plasma iodine rose during the lithium-free period from 0.25 to $0.43 \mu \mathrm{g} . / 100 \mathrm{ml}$. Resumption of lithium treatment led to a fall of plasma inorganic iodine to $0.21 \mu \mathrm{g}$./ $100 \mathrm{ml}$. , and at the same time thyroid clearance rose to $56 \mathrm{ml}$./ min. ; absolute iodine uptake remained unaltered. Two other patients (Cases 6 and 7) stopped taking lithium of their own accord. In one of these (Case 7) this led to a fall in tracer uptake, thyroid clearance, and absolute iodine uptake ; thyroid clearance did not become completely normal, and inorganic plasma iodine rose after discontinuance of lithium. The other patient (Case 6) had not been studied with ${ }^{132}$ I before lithium was discontinued, but investigation three months after resumption of treatment showed increase of tracer uptake and thyroid clearance to abnormally high values.' Inorganic plasma iodine fell to $0.05 \mu \mathrm{g} . / 100 \mathrm{ml}$; absolute iodine uptake remained unaltered.

Investigation of seven patients who had not developed goitre during lithium treatment showed slight increase of inorganic plasma iodine and absolute iodine uptake in two cases. All other values were normal.

\section{Prevalence and Incidence}

On 1 January 1968115 of the patients at the Psychiatric Clinic were being treated with lithium either while in hospital or at outpatient clinics. On this date seven patients had goitre; in two others thyroidectomy had been performed previously. Goitre prevalence was therefore $8 \%$.

The first cases of goitre were recorded in 1964. During the four-year period 1964-7 lithium was administered to 330 patients at the Psychiatric Clinic. About $40 \%$ were women and $60 \%$ men; $15 \%$ received lithium for less than a month, $50 \%$ for between one month and one year, and $35 \%$ for longer than a year. The 12 cases of goitre developed during a total treatment period of 320 lithium-patient-years. Goitre incidence-that is, the likelihood of goitre developing among 100 patients during continuous lithium treatment for one yearwas accordingly $4 \%$. If there is a latency period for goitre development the incidence becomes higher.

\section{Discussion}

To what extent is lithium incriminated as a goitrogenic agent by these observations of goitre development among Danish patients who suffered from recurrent manic-depressive disorder and were given lithium for shorter or longer periods, often with neuroleptic and antidepressant drugs ?

The frequency of goitre in Denmark is usually considered to be relatively low (W.H.O., 1960), but it varies within the country. Prevalences of 2 and $15 \%$ have been recorded, the

Thyroid Values in Patients Who Developed Goitre during Lithium Treatment. Italics Indicate Values Outside the Normal Range

\begin{tabular}{|c|c|c|c|c|c|c|c|c|c|c|c|}
\hline & & \multirow[b]{2}{*}{ Normal Range } & \multicolumn{5}{|c|}{ Case 1} & \multicolumn{3}{|c|}{ Case 2} & \multirow{2}{*}{$\frac{\text { Case } 5}{\text { Oct. }_{1965 \text { (d) }}}$} \\
\hline & & & $\begin{array}{l}\text { Dec. } \\
1965\end{array}$ & $\begin{array}{l}\text { Oct. } \\
1967\end{array}$ & $\begin{array}{l}\text { Nov }_{\text {(a) }} \\
1967 \text { (a) }\end{array}$ & $\begin{array}{l}\text { Feb } \\
1968 \text { (b) }\end{array}$ & $\begin{array}{c}\text { Mar. } \\
1968 \text { (c) }\end{array}$ & $\begin{array}{l}\text { Feb. } \\
1966\end{array}$ & $\begin{array}{l}\text { Nov. } \\
1967\end{array}$ & $\begin{array}{l}\text { Dec. } \\
1967\end{array}$ & \\
\hline 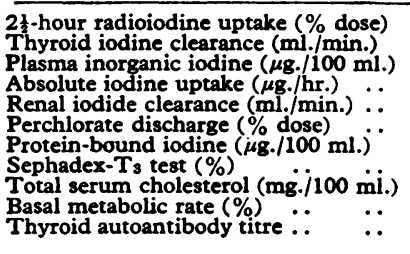 & 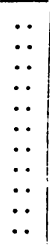 & $\begin{array}{c}10-45 \\
10-60 \\
0 \cdot 08-0 \cdot 25 \\
0 \cdot 8-5 \cdot 0 \\
15-50 \\
<15 \\
3 \cdot 0-7 \cdot 5 \\
4 \cdot 4-6 \cdot 8 \\
150-335 \\
-15 \text { to }+15 \\
<5\end{array}$ & $\begin{array}{l}24 \\
77 \\
0 \cdot 25 \\
11 \cdot 5 \\
16 \\
<15 \\
5 \cdot 2 \\
5 \cdot 3 \\
300 \\
-11 \\
<5\end{array}$ & $\begin{array}{c}36 \\
107 \\
0 \cdot 25 \\
16 \cdot 0 \\
16 \\
<15 \\
4 \cdot 2 \\
5 \cdot 8 \\
286 \\
-6 \\
<5\end{array}$ & $\begin{array}{c}4 \\
27 \\
0 \cdot 54 \\
8 \cdot 7 \\
16 \\
<15 \\
4 \cdot 0 \\
6 \cdot 0 \\
219\end{array}$ & $\begin{array}{c}17 \\
28 \\
0.43 \\
7.2 \\
28\end{array}$ & $\begin{array}{c}25 \\
56 \\
0.21 \\
7.1 \\
23 \\
<15 \\
4.6 \\
5.6 \\
308\end{array}$ & $\begin{array}{c}45 \\
126 \\
0 \cdot 11 \\
8 \cdot 3 \\
67 \\
<15 \\
5 \cdot 7 \\
4 \cdot 7 \\
245 \\
-12 \\
<5\end{array}$ & $\begin{array}{c}33 \\
75 \\
0.10 \\
4.5 \\
54 \\
<15 \\
7.4 \\
5 \cdot 4 \\
260 \\
<5\end{array}$ & $\begin{array}{c}36 \\
73 \\
0.07 \\
3 \cdot 1 \\
60 \\
<15 \\
5 \cdot 2 \\
5 \cdot 5 \\
253 \\
<5\end{array}$ & $\begin{array}{c}64 \\
218 \\
0.05 \\
6.5 \\
30 \\
<15 \\
2.6 \\
4.4 \\
228 \\
-1 \\
<5\end{array}$ \\
\hline
\end{tabular}

\begin{tabular}{|c|c|c|c|c|c|c|c|c|c|c|c|}
\hline & \multirow[b]{2}{*}{$\begin{array}{c}\text { Normal } \\
\text { Range }\end{array}$} & \multicolumn{2}{|c|}{ Case 6} & \multicolumn{2}{|c|}{ Case 7} & \multicolumn{2}{|c|}{ Case 9} & \multirow{2}{*}{$\begin{array}{c}\text { Case } 10 \\
\text { Dec. } \\
1967\end{array}$} & \multirow{2}{*}{$\begin{array}{c}\text { Case } 13 \\
\begin{array}{c}\text { Feb. } \\
1967\end{array}\end{array}$} & \multirow{2}{*}{ 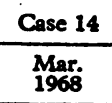 } & \multirow{2}{*}{$\begin{array}{c}\text { Case } 15 \\
\begin{array}{c}\text { Feb. } \\
1968\end{array}\end{array}$} \\
\hline & & $\begin{array}{c}\text { Nov. } \\
1967(\mathrm{e})\end{array}$ & $\begin{array}{c}\text { Feb. } \\
1968(\mathrm{f})\end{array}$ & $\begin{array}{l}\text { Jan. } \\
1967\end{array}$ & $\begin{array}{c}\text { Feb. } \\
1968 \text { (g) }\end{array}$ & $\begin{array}{l}\text { June } \\
1967\end{array}$ & $\begin{array}{l}\text { April } \\
1968\end{array}$ & & & & \\
\hline 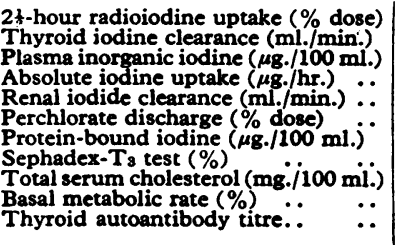 & \begin{tabular}{|c|}
$10-45$ \\
$10-60$ \\
$0.08-0 \cdot 25$ \\
$0.8-5 \cdot 0$ \\
$15-50$ \\
$<15$ \\
$3 \cdot 0-7 \cdot 5$ \\
$4 \cdot 4-6 \cdot 8$ \\
$150-335$ \\
-15 to +15 \\
$<5$
\end{tabular} & $\begin{array}{c}27 \\
60 \\
0 \cdot 12 \\
4 \cdot 3 \\
56 \\
<15 \\
5 \cdot 2 \\
5 \cdot 7 \\
210 \\
<5\end{array}$ & $\begin{array}{c}51 \\
144 \\
0.05 \\
4.3 \\
15 \\
5 \cdot 2 \\
5.8 \\
226 \\
<5\end{array}$ & $\begin{array}{c}66 \\
224 \\
0.04 \\
5 \cdot 6 \\
62 \\
<15 \\
5 \cdot 3 \\
6 \cdot 1 \\
274 \\
+8 \\
<5\end{array}$ & $\begin{array}{c}30 \\
68 \\
0.09 \\
3.7 \\
54 \\
<15 \\
5.0 \\
6.3 \\
254 \\
<5\end{array}$ & $\begin{array}{c}76 \\
237 \\
0 \cdot 06 \\
8 \cdot 5 \\
23 \\
<15 \\
4 \cdot 2 \\
6 \cdot 1 \\
180 \\
-2 \\
<5\end{array}$ & $\begin{array}{c}73 \\
364 \\
0.06 \\
13.0 \\
13 \\
<15 \\
3.6 \\
5.4 \\
166 \\
<5\end{array}$ & $\begin{array}{c}25 \\
29 \\
0 \cdot 12 \\
2 \cdot 1 \\
23 \\
<15 \\
4 \cdot 3 \\
5 \cdot 1 \\
290 \\
<5\end{array}$ & $\begin{array}{c}61 \\
150 \\
0.03 \\
2.7 \\
42 \\
<15 \\
21.3 \\
4.5 \\
29.4 \\
+8\end{array}$ & $\begin{array}{c}73 \\
338 \\
0 \cdot 03 \\
8 \cdot 1 \\
69 \\
<15 \\
3.4 \\
5.3 \\
214 \\
<5\end{array}$ & $\begin{array}{c}5 \\
72 \\
0.06 \\
2.6 \\
42 \\
<15 \\
4 \cdot 5 \\
5 \cdot 3 \\
325 \\
<5\end{array}$ \\
\hline
\end{tabular}

(a) After administration of $\mathrm{L}$-triiodothyronine, 120 er. per day for 8 days. (b) After 3 months without lithium (c) One month after resumption of lithium (d) B (a) After administration of $\mathrm{L}$-triiodothyronine, 120 mg per day for 8 days. (b) After 3 months without lithium. (c) One month after resing
operation. (e) After a few months without lithium. (f) Three months after resumption of lithium. (g) After a few months without lithium. 
latter in a goitre region (Rosenquist, 1943). No statistics are available on goitre prevalence or incidence in the district from which our patients come. In a group of women from the Copenhagen region Bartels (1941) found a disease expectancy for goitre of $1.1 \%$ and estimated the corresponding figure for men to be lower. Disease expectancy is the risk of falling ill during a lifetime. Seen in this relation, the goitre incidence among tithium-treated patients-that is, the risk of developing goitre during a single year-is distinctly increased.

The patients suffered from recurrent manic-depressive disorder. No reliable studies are available concerning frequency of thyroid disorders among manic-depressive subjects. One study of P.B.I. among manic-depressives showed an average value lower than in the control group but within the normal range (Bowman et al., 1950); later studies have not disclosed significant differences (Board et al., 1957 ; Gibbons et al., 1960). Longitudinal studies of patients with periodic psychoses showed in some cases variation of thyroid function with the clinical condition (R. Gjessing, 1938 ; L. R. Gjessing, 1964 ; Libow and Durell, 1965); in other studies the thyroid values did not change (Gornall et al., 1953 ; Gunne and Gemzell, 1956).

At the time goitre developed some of our patients received, in addition to lithium, neuroleptic or antidepressant drugs or both. Animal experiments concerning the action of neuroleptic and antidepressant drugs on thyroid function have been inconclusive. In some patients treatment with perphenazine has led to increase of P.B.I., possibly caused by impurities in the tablets (Cranswick et al., 1965 ; Hansen and SiersbækNielsen, 1967). No reports have been published on lowering of P.B.I. or of increased goitre frequency during the use of neuroleptic or antidepressant drugs.

It would have been desirable to compare goitre frequency among lithium-treated patients with the frequency in a control group of patients who had not been given lithium. We are, however, unable to make such a comparison, because almost all our patients with recurrent manic-depressive disorder are now receiving lithium, and retrospective studies of goitre frequency on the basis of psychiatric case notes cannot be regarded as reliable. Our data indicate that goitre frequency is increased among lithium-treated patients. This may not in itself provide conclusive evidence that lithium is goitrogenic, but it does put lithium under suspicion.

This suspicion is supported by the temporal relation of goitre development and lithium administration. The goitres developed or increased in size within periods of five months to two years after the patients were put on lithium. More signifcantly, discontinuance of lithium led to shrinkage or disappearance of the goitres within a few months.

Further support for assuming a relation between goitre development and lithium administration is provided by the observations that thyroid iodine clearance rose when lithium treatment was resumed after an interval, and that there was a fall of tracer uptake and thyroid clearance after discontinuance of lithium. Both values may vary during continuous lithium administration, but the changes were more pronounced on discontinuance and resumption of the treatment. Effects of lithium on thyroid function have also been reported by Sedvall et al. (1968).

The mechanism by which lithium interferes with thyroid function is still obscure. We do not know whether it is of significance that lithium reaches a somewhat higher concentration in the thyroid than in other tissues. Lithium concentration was about four times higher in the thyroid than in serum in the patient studied by us. In rats having received lithium with their food for two weeks, the lithium concentration in the thyroid was three times and in liver, brain, muscle, and kidney between 0.6 and 1.7 times the serum concentration (Amdisen and Thomsen, 1968).

The increase of tracer uptake and thyroid iodine clearance might be caused by a direct lithium action on the hypothalamic- pituitary system with stimulation of thyroid stimulating hormone (T.S.H.) or T.S.H.-releasing factor. However, since P.B.I. values were normal or low, it is more likely that lithium primarily inhibited hormone production in the thyroid, and that this led to compensatory increase of T.S.H. secretion with consequent hyperplasia of the thyroid gland. The pronounced effect of the suppression test supports this view.

Goitre developed in only a limited number of the patients who were given lithium. In most of the patients who did not develop goitre during the treatment, thyroid values were normal. We are therefore led to conclude that lithium plays only a contributory part and that goitre does not develop unless other factors are also at work. Iodine deficiency is a possibility. Only in one of our patients was the concentration of inorganic plasma iodine relatively high; in the others it was at or below the lower normal limit. In lithium-treated patients without goitre the average inorganic plasma iodine $(0.21 \mu \mathrm{g} . / 100 \mathrm{ml}$.) did not differ significantly from that of normal persons $(0.13$ $\mu \mathrm{g} . / 100 \mathrm{ml}$.). The reason for the low concentration of inorganic plasma iodine in the goitre patients is not clear. A marginal iodine intake is possible, but only two of our patients reported particular dietary habits (infrequent fish-eating). Since some of the goitre patients showed a slight increase of renal iodide clearance the low plasma levels might be of renal origin; however, no correlation could be noted between low inorganic plasma iodine and increase of renal iodide clearance.

It is more likely that the low inorganic plasma iodine among the goitre patients was due to direct action of lithium on hormone synthesis in the thyroid gland. This assumption is supported by the observation of increase in inorganic plasma iodine after discontinuance of lithium and fall after resumption of treatment. It should further be noted that in six goitre patients thyroid iodine clearance was so high that absolute iodine uptake of the gland exceeded the normal range. This is not usually found among patients with goitre caused by simple iodine deficiency, but is characteristic of faulty utilization of iodine such as can be seen in congenital defects of hormone synthesis or when synthesis is inhibited by goitrogens.

Since the uptake of radioactive iodine was normal or increased among the goitre patients, and since there were no instances of increased discharge of radioactivity after perchlorate, the iodide trap and the incorporation of iodine into tyrosine cannot have been affected by lithium. Hormone synthesis must be influenced at a later stage. Production of metabolically inactive iodinated proteins is not likely, since P.B.I. tended to low rather than high values. Dehalogenation or coupling of iodotyrosines may have been partially inhibited. The former would result in lowered intraglandular reutilization of iodine liberated by thyroglobulin proteolysis, leading eventually to secondary iodine deficiency. Studies are in progress to throw further light on iodine metabolism and thyroid function in goitres developing during lithium treatment.

\section{Conclusion}

Goitre is not a frequent side-effect or complication of lithium treatment; nor is it a serious one. Among the cases so far observed none has shown signs of malignancy or development of permanent thyroid dysfunction. Our observations indicate that goitres appearing during lithium treatment do not differ in course and clinical picture from other nontoxic goitres and that treatment with small doses of thyroxine or desiccated thyroid may stop further growth of the gland or lead to shrinkage of the goitre even when lithium administration is continued.

The studies with radioactive iodine were carried out in collaboration with the Departments of Biophysics and Clinical Chemistry, Aarhus University. 


\section{REFERENCBS}

Alezander, W. D., et al. (1962). Quart. F. Med., 31, 281. Allgén, L.-G., Almgren, S., and Mărtens, S. (1967). Report at Symposium on "Lithium and Goitre" in Risskov.

Amdisen, A., and Thomsen, K. (1968). Unpublished observations. Basurup, P.'C. (1967). Report at Symposium on "Lithium and Goitre" in Risskov.

Baastrup, P. C., and Schou, M. (1967). Arch. gen. Psychiat., 16, 162.

Bartels, B. D. (1941). Heredity in Graves' Disease. Copenhagen.

Board, F., Wadeson, R., and Persky, H. (1957). Arch. Neurol. Psychiat., 78, 612 .

Bowman, K. M., Miller, E. R., Dailey, M. E., Simon, A., and Mayer, B. F. (1950). 7. nerv. ment. Dis., 112, 404.

Cranswick, E. H., Cooper, T. B., and Simpson, G. M. (1965). Amer. 7. Psychiat., 122, 300.

Gibbons, J. L., Gibson, J. G., Marwell, A. E., and Willcox, D. R. C. (1960). \%." psychosom Res., 5, 32.

Giessing, L. R. (1964). Y. psychiat. Res., 2, 123.

Gjessing, R. (1938). \%. ment. Sci., 84, 608.
Gonzales, R., and Lauter, H. (1968). Nervenarzt, 39, 11

Gornall, A. G., Eglitis, B., Miller, A., Stokes, A. B., and Dewan, J. G. (1953). Amer. Y. Psychias., 109,'584.

Gunne, L. M., and Gemzell, C. A. (1956). Acta psychiat. scand., 31, 367. Halberg, P.o, Dige-Petersen, H., Werdelin, O., Simonsen, J., and Rafaelsen, O. J. (1968). Ugeskr. Lag. In press.

Hansen, H. H. (1966). Scand. Y. clin. Lab. Invest., 18, 240.

Hansen, J. M., and Siersbrek-Nielsen, K. (1967). Acta endocr. (Kbh.), 55, 136.

Hjost, T. (1963). Acta med. scand., 174, 147.

Jensen, S. Eskjer (1968). Unpublished dato.

Libow, L. S. and Dureli, J. (1965). Psychosom. Med. 27, 369.

Pearson, S., Stern, S., and McGavack, T. H. (1953). Analyt. Chem., 25, 813.

Rosenquist, K. (1943). Om strumaploblemet pea Grundlag of. en Undorsogelse i tre danske Landsogne. Copenhagen.

Schou, M. (1968). F. psychiat. Res., 6, 67.

Sedvall, G.. Jönsson, B., and Pettersson, U. (1968). Acta psychiat. scand. In press.

W.H.O. (1.960). Wld Hlth Org. Monogr. Ser., No. 44.

Wiggers, S. (1968). Ugeskr. Lag. In press.

\title{
Urinary Schistosomiasis Treated with Sodium Antimony Tartrate- a Quantitative Evaluation*
}

\author{
Z. FARID, $\dagger$ M.D., D.T.M.\&H. ; S. BASSILY, M.B.; D. C. KENT, M.D. ; A. HASSAN,§ M.B., D.M. \\ M. F. ABDEL-WAHAB,\| M.D., D.T.M.\&H.; J. WISSA, $†$ M.SC.
}

Brit. med. Y., 1968, 3, 713-714

\begin{abstract}
Cummary : Seventeen Egyptian male farm-workers aged N 8 to 27 years infected with Schistosoma haematobium were given twice-weekly intravenous injections of sodium antimony tartrate in a dose of $0.5 \mathrm{~g}$. ( $30 \mathrm{mg}$.) per $15 \mathrm{~kg}$. body weight for 12 injections. Bell's egg-count technique was used to evaluate results on 24-hour urine collections before and at $1,4,8$, and 12 weeks after treatment. Patients were considered to be cured only when there were no eggs in the urine when examined by the filtration-staining, miracidial-hatching, and 24-hour urinesediment examination methods.
\end{abstract}

At the final follow-up 14 out of 17 patients were found not to be passing eggs in the urine-an $82 \%$ cure rate. The mean reduction in egg output in the remaining three patients was $99 \%$. These results are superior to any reported for other antimony drugs.

\section{Introduction}

We recently reported on the treatment of 34 Egyptian male farmers infected with schistosomiasis with sodium antimony dimercaptosuccinate (stibocaptate, Astiban) (Farid et al., 1966, 1967a). Bell's (1963) quantitative egg-count technique was used to evaluate results. Three months after treatment the mean egg output was reduced by $90 \%$, with a cure rate of $12 \%$ in patients infected with Schistosoma haematobium and $29 \%$ in those infected with $S$. mansoni. Bell (1964), using Astiban and approximately the same techniques to evaluate results of treatment, reponted similar findings from East Africa.

\footnotetext{
- The opinions and assertions contained herein are the private ones of the authors and are not to be construed as official or reflecting the views of the Navy Department, the Naval service at large, or the Egyptian Ministry of Public Health.

† Staff, U.S. Naval Medical Research Unit No. 3, Cairo, Egypt.

‡ Director, U.S. Naval Medical Research Unit No. 3, Cairo, Egypt.

Director, Abbassia Fever Hospital, Ministry of Public Health

|| Lecturer, Tropical Disease Unit, Kasr-El-Aini Hospital, Cairo University.
}

Sodium antimony tartrate (tartar emetic), the first drug successfully used in the treatment of schistosomiasis, is still considered by many authorities to be the most effective schistosomicidal drug. It should therefore be used as a reference with which to compare therapeutic results obtained in the treatment of schistosomiasis with newer drugs. Applying the same techniques as those used in our previous study and working under the same hospital conditions, we treated with tartar emetic 17 Egyptian male farmers infected with $S$. haematobium. This paper presents our findings and compares them with our previous results and those of others.

\section{Patients and Methods}

Seventeen Egyptian male farm-workers aged 8 to 27 years infected with $S$. haematobium were treated with tartar emetic. They lived in the same villages from which previous patients had been obtained (villages in the Nile Delta, usually within 100 kilometres of Cairo). Bell's (1963) egg-count technique was used on 24-hour urine collections taken on two consecutive days before treatment and at $1,4,8$, and 12 weeks after treatment. Repeated miracidial hatching tests were performed at the 12-week follow-up period. All patients were passing over 10,000 eggs per day and all were kept in hospital during the three-month follow-up period. Tartar emetic was given at a dosage of $0.5 \mathrm{~g}$. (30 mg.) per $15 \mathrm{~kg}$. body weight twice weekly for 12 doses. It was given intravenously slowly over a 10-minute period.

Ten of the 17 patients had received previous treatment with tartar emetic about a year before this study was undertaken, yet 13 of the 17 complained of severe haematuria accompanied by dysuria and four complained of terminal haematuria when admitted to hospital.

\section{Results}

The results are recorded in Tables I and II. A marked reduction in egg output occurred immediately after treatment 